\title{
Remediation of Acid Mine Drainage Based on a Novel Coupled Membrane-Free Microbial Fuel Cell with Permeable Reactive Barrier System
}

\author{
Tang Hai*, Pu Wen-Cheng, Cai Chang-Feng*, Xu Jian-Ping, He Wen-Jun \\ School of Biochemical Engineering, Anhui Polytechnic University, \\ Beijing Mid-road No. 10, Wuhu, Anhui, China, 241000 Wuhu, China
}

Received: 13 October 2015

Accepted: 4 December 2015

\begin{abstract}
In this study, a coupled membrane-free microbial fuel cell (MFC) with permeable reactive barrier (PRB) was reported and its treatment performance and electricity generation for acid mine drainage (AMD) were examined. The pilot-scale continuous flow MFC-PRB was operated for five periods at a hydraulic retention time of $48.0 \mathrm{~h}$, and the average sulphate removal percentages of $51.2 \%, 39.8 \%$, and $33.1 \%$ were obtained in effluent of $1,000,2,000,3,000 \mathrm{mg} / 1$, respectively. More than $99.5 \%$ of the initial concentrations of $\mathrm{Cu}^{2+}$, $\mathrm{Zn}^{2+}$, and $\mathrm{Pb}^{2+}$ were removed, resulting in concentrations of those elements of $0.01-0.05 \mathrm{mg} / \mathrm{l}$ in the effluent. The results demonstrated that the MFC-PRB holds a potential capacity for remediation of AMD.
\end{abstract}

Keywords: membrane-free microbial fuel cell, permeable reactive barrier, acid mine drainage, bio-remediation, electricity generation

\section{Introduction}

Acid mine drainage (AMD), resulting from the chemical reaction of oxygen and water (or atmospheric humidity) with sulfide minerals (e.g., pyrite), has a relation with the release of acidic, sulphate, and metalcontaining $(\mathrm{Pb}, \mathrm{Fe}, \mathrm{Cd}, \mathrm{Cu}, \mathrm{Zn}$, etc.) wastewater. AMD can contaminate both ground and surface waters and has been recognized as one of the more serious elements of environmental pollution in China and around the world, and is currently being studied by several researchers [1-7].

There are various techniques available for remediation

*e-mail: newth76@163.com of AMD, which may be divided into either chemical or biological mechanisms to remove metals from solution. A number of reported studies have shown that a bioreactor based on $n \mathrm{ZVI}$ and sulfate-reducing bacteria (SRB) media can be applied for the treatment of a real acid water system containing a mixture of sulphate, heavy metals, and low $\mathrm{pH}$-value pollutants [8-10]. Furthermore, permeable reactive barriers (PRB) as an alternative option for in-situ removal of contaminated groundwater [10-12] have been used widely to provide treatment of contaminants from AMD [13-15]. In addition, we assessed the efficiency of new design structure PRBs to remove heavy metals from AMD and the potential of municipal compost as a carbon source for SRB to enhance metal sulfide precipitation in AMD bioremediation at high flow rates [16-21]. 
Microbial fuel cells (MFCs) use microorganisms as catalysts to generate electricity directly from organic compounds that have been developed as a promising technology to recover energy from wastewater, sludge, etc. [22-24]. As shown here and in previous research, MFCs can be used to treat AMD or sulphate wastewater and generate electricity [25-30]. However, there has been little in literature reporting an MFC-PRB system in relation to remediation of AMD. The aim of the present study was to construct a coupled MFC with a PRB system and investigate treatment efficiency and electricity generation, thereby gaining some insights into the AMD bioremediation mechanistic understanding for the potential utilities.

\section{Materials and Methods}

Simulated AMD, Sludge, and SRB Inoculums

AMD was characterized for its $\mathrm{pH}$, metals content, and sulphate concentration (see Table 1), which consisted of $\mathrm{NH}_{4} \mathrm{Cl} \quad 0.191 \mathrm{~g} / \mathrm{l}, \mathrm{K}_{2} \mathrm{HPO}_{3} \quad 0.075 \mathrm{~g} / \mathrm{l}, \quad \mathrm{Na}_{2} \mathrm{SO}_{4}$ $2.215 \mathrm{~g} / \mathrm{l}, \mathrm{MgSO}_{4} \cdot 7 \mathrm{H}_{2} \mathrm{O} 3.844 \mathrm{~g} / \mathrm{l}, \mathrm{CuCl}_{2} \cdot 2 \mathrm{H}_{2} \mathrm{O} 0.0797 \mathrm{~g} / \mathrm{l}$, $\mathrm{FeSO}_{4} \cdot 7 \mathrm{H}_{2} \mathrm{O} 0.149 \mathrm{~g} / \mathrm{l}, \mathrm{Pb}\left(\mathrm{NO}_{3}\right)_{2} 0.0479 \mathrm{~g} / 1, \mathrm{ZnCl}_{2} 0.0628$ $\mathrm{g} / \mathrm{l}$, and $\mathrm{Cd}\left(\mathrm{NO}_{3}\right)_{2} \cdot 4 \mathrm{H}_{2} \mathrm{O} 0.0825 \mathrm{~g} / \mathrm{l}$. The contaminants were dissolved in tap water to synthesize simulative influent wastewater, and supplemented further by sulphate whenever necessary. Sewage sludge obtained from an anaerobic sludge digester of a municipal wastewater treatment plant in Wuhu, China, was used as inoculums into the anodic zone. The sludge samples were filtered using a 40-mesh sieve to remove the larger particles and stored at $4^{\circ} \mathrm{C}$ before use. An appropriate amount of glucose was added to the sludge and its total suspended solids (TSS) and volatile suspended solids (VSS) were $2.45 \mathrm{~g} / 1$ and $1.56 \mathrm{~g} / \mathrm{l}$, respectively. The presence of SRB was showed by blackening precipitates in the test tube from the fourth day of incubation at $20^{\circ} \mathrm{C}$ to $30^{\circ} \mathrm{C}$.

\section{A Coupled MFC with PRB Setup}

The pilot-scale continuous flow MFC-PRB system was carried out employing parallel acrylic material columns ( $14.5 \mathrm{~cm}$ i.d., $70 \mathrm{~cm}$ high), which were separated by a plate with a center hole $(3 \mathrm{~cm}$ i.d.). The exterior chamber was used as PRB packed with corn cob media and inoculated by SRB, and the cathode electrode was placed at the end of an exterior chamber and covered with another end plate. The inner chamber was directly used as an anode area that filled with excess sludge. The anode and cathode electrode were a piece of $43.4 \mathrm{~cm}(1.5 \mathrm{~cm}$ i.d.,
$45 \mathrm{~cm}$ high) carbon rod and carbon felt $(4.5 \mathrm{~cm}$ i.d., $50 \mathrm{~cm}$ high, Beijing) without any pretreatment and which were connected through a $1,000 \mathrm{x}$ resistor. The ceramic mixtures near the inlets as supporting material were installed at the bottom of the MFC-PRB to simulate a natural aquifer and ensure flow distribution. MFC-PRB was operated for five periods at room temperature of $25 \pm 3^{\circ} \mathrm{C}$. The influent sulphate concentration was maintained at $1000 \mathrm{mg} / \mathrm{l}$ until period $1-3$, and its concentration was increased to $2,000 \mathrm{mg} / 1$ in period four, and then to $3,000 \mathrm{mg} / \mathrm{l}$ in the last period. The $500 \mathrm{ml}$ sludge (without any pre-treatment) was added to the anode chambers to produce electricity at periods 1,3 , and 5 . The MFC-PRB system was continuously fed with synthetic AMD in a downflow mode using multiport peristaltic pumps. The HRT was maintained at about $48.0 \mathrm{~h}$.

\section{Analytical Methods, Instruments, and Data Processing}

Unfiltered samples were immediately measured for $\mathrm{pH}$ (PHB-10, Shanghai Leici). Some portion of samples (about $50 \mathrm{ml}$ ) were filtered with $0.45 \mu \mathrm{m}$ membrane filters, and the filtrate was immediately analyzed for sulphate (Barium Chromate Spectrophotometry) using a TU 1901 spectrophotometer (Beijing Purkinje General Instrument Co., Ltd.). The remaining filtrates were acidified using concentrated $\mathrm{HNO}_{3}$ and transported to a laboratory for metal analysis.

Concentrations of $\mathrm{pb}, \mathrm{Cd}, \mathrm{Cu}, \mathrm{Fe}$, and $\mathrm{Zn}$ were measured with a flame atomic absorption spectrophotometer (WFX-100, Beijing Beifen-Ruili Analytical Instrument Co. Ltd.). The COD was determined by the standard method using chromate as the oxidant as previously described [31]. Samples were sputter-coated with a mixture of gold and palladium. Scanning electron microscopy SEM (S-4800, Hitachi, Japan) equipped with an energy dispersive spectrometer (EDS) was used to determine the elemental ratio and cathode carbon felt surface compositions. All the analyzed elements were normalized and were repeated five times.

\section{Results and Discussion}

\section{Effluent COD and Electricity Generation Performance}

The electricity generation performances and effluent COD are shown in Fig. 1. During the MFC-PRB process at period 1 , the circuit voltage increased and reached 190 $230 \mathrm{mV}$. The initial effluent concentration of COD was $761 \mathrm{mg} / \mathrm{l}$, which shows electroactive bacteria that

Table 1. Characteristics of AMD used in the tests.

\begin{tabular}{|c|c|c|c|c|c|c|c|}
\hline Parameters & $\mathrm{pH}$ & $\mathrm{Pb}$ & $\mathrm{Cd}$ & $\mathrm{Cu}$ & $\mathrm{Zn}$ & Total Fe & $\mathrm{SO}_{4}^{2-}$ \\
\hline Value & $4 \sim 6$ & $20 \mathrm{mg} / \mathrm{l}$ & $20 \mathrm{mg} / \mathrm{l}$ & $20 \mathrm{mg} / 1$ & $20 \mathrm{mg} / \mathrm{l}$ & $20 \mathrm{mg} / \mathrm{l}$ & $3000 \mathrm{mg} / \mathrm{l}$ \\
\hline
\end{tabular}


might be feasibly enriched from the initial microbial source in an anodic chamber and oxidized organic matter as carbon sources to support microbial activity. However, there was a sharp decrease of voltage at period 2, which is reduced to a minimum of $52 \mathrm{mV}$, and then a portion of superior decrease in COD was observed due to organic matter biodegradation providing for bioelectricity generation. At periods 3-5, COD value increased slightly and remained steady at around 311-536 mg/l, indicating that residual COD was very likely affecting bioavailability for bioelectricity generation, whereas the trend of COD removal in MFC-PRB was almost in parallel with the voltage profile, which is relatively stable at low levels.

When compared with other two-chamber MFC studies for treating sulphate wastewater from glucose and acetate, the electricity production was similar [5, 25]. Nevertheless, Liu et al. [32] obtained $220.7 \mathrm{~mW} / \mathrm{m}^{2}$ using a single chamber floating-cathode MFC employing sludge as the substrate, although electricity production in the present study was lower. These differences are probably a consequence of the type and structure of MFC employed. Consequently, the results demonstrated that the treatment of AMD using excess sludge as the MFC-PRB anode substrate is effective.

\section{Sulphate Reduction}

The influent and effluent sulphate concentrations and sulphate reduction percentage are presented in Fig. 2. It was observed that the average $\mathrm{SO}_{4}^{2-}$ removal rate percentage with $1,000 \Omega$ were $51.2 \%, 39.8 \%$, and $33.1 \%$ with influent concentrations of 1,000, 2,000, and 3,000 $\mathrm{mg} / \mathrm{L}$, respectively. The corresponding sulphate reduction rates were $1.2 \mathrm{~g} / \mathrm{d}, 3.0 \mathrm{~g} / \mathrm{d}$, and $5.0 \mathrm{~g} / \mathrm{d}$ at periods $3-5$, respectively. Some similar results reported that the total sulphate removal efficiencies of the proposed system achieved 52.7\% using a new type of UASB-MFC [33] treating molasses wastewater; otherwise Zhao et al. [34] found that sulphate $\left(3.03 \mathrm{~g} / \mathrm{dm}^{3}\right)$ represented $99 \%$ removal by use of activated carbon cloth as an anode in MFC-based single-chamber air-breathing treating organic wastewater

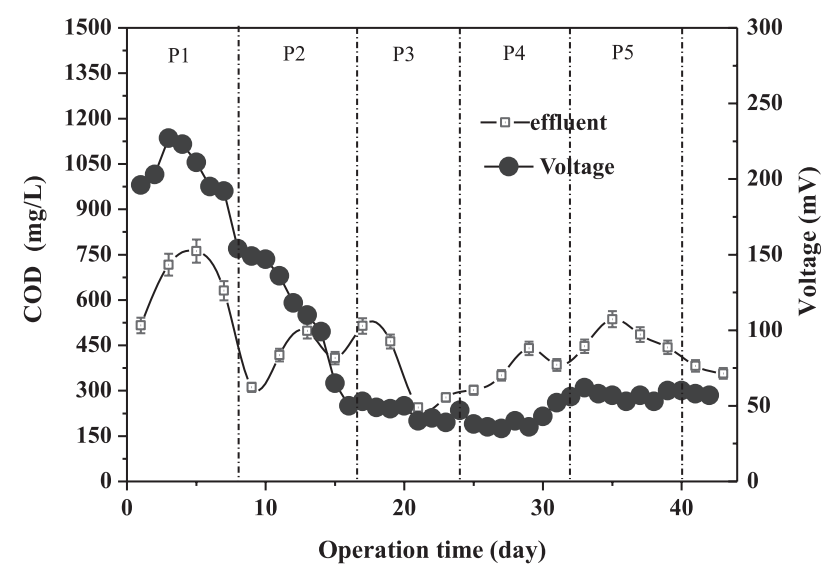

Fig. 1. Effluent of COD and voltage for the MFC-PRB reactor treating AMD.

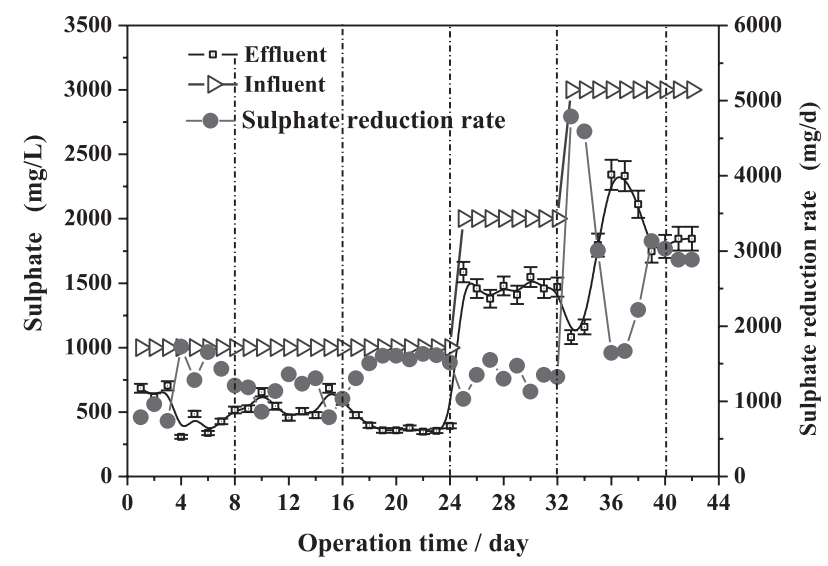

Fig. 2. Sulphate reduction for an MFC-PRB reactor treating AMD.

containing high sulphate [35]. It seems that a lower removal rate can account for the fact that the excessive concentration of sulphates are biologically toxic; thus, they may hinder the growth of microorganisms, including the SRB bacteria, electrogenic bacteria, and other bacteria [35].

\section{Heavy Metals Removal}

The heavy metals removal results are depicted in Fig. 3. We found that the removal of $\mathrm{Cu}^{2+}, \mathrm{Pb}^{2+}$, and $\mathrm{Zn}^{2+}$ were very effective and stable with average effluent between $0.01-0.05 \mathrm{mg} / 1$ for all concentrations from the AMD throughout the process, and removal efficiency reached $99.9 \%, 99.5 \%$, and $99.6 \%$. Moreover, average $\mathrm{Cu}^{2+}$ concentrations decreased to $<0.02 \mathrm{mg} / \mathrm{l}$. By contrast, the effluent concentration of $\mathrm{Cd}^{2+}$ weakly fluctuated throughout the process - especially total Fe effluent concentration in AMD, which suddenly increased to a peak value of $3.84 \mathrm{mg} / \mathrm{l}$ on day 7 followed by a gradual decrease on day 9 until day 29, then was reduced to below $0.5 \mathrm{mg} / \mathrm{l}$ on day 31 . Removal efficiency was maintained at $80.9 \%$ to $99.1 \%$.

It was inferred that a high-level removal of $\mathrm{Zn}^{2+}, \mathrm{Pb}^{2+}$, and $\mathrm{Cu}^{2+}$ was established due to the low-solubility products of zinc sulfide $\left(\mathrm{K}_{\mathrm{sp}}=1.3 \times 10^{-24}\right)$, lead sulfide $\left(8 \times 10^{-28}\right)$, and copper sulfide $\left(\mathrm{K}_{\mathrm{sp}}=1.3 \times 10^{-36}\right)$, independent of initial concentrations of sulphate. Compared with the previous studies, $99 \%$ of $\mathrm{Cu}^{2+}$ was removed with the effluent concentration at $0.2 \mathrm{mg} / \mathrm{l}$, and $\mathrm{Fe}^{2+}$ was decreased from $545 \mathrm{mg} / \mathrm{l}$ to $75 \mathrm{mg} / \mathrm{l}$ in effluent when the AMD was treated by $\mathrm{SRB}$ and $\mathrm{Fe}^{0}[9]$. It could be concluded that MFC-PRB enhanced the removal of heavy metals in comparison to controls with SRB biological treatment.

The heavy sulfide precipitated in cathode obtained from carbon felt were confirmed and studied using SEM and EDS. The conversions of sulfur compounds and heavy metals are presented in Fig. 4. SEM/EDS spectra were found to contain high $\mathrm{Cd}, \mathrm{Fe}, \mathrm{Pb}, \mathrm{Zn}$, and $\mathrm{Cu}$ concentrations, suggesting that heavy metals precipitation crystals may have formed on the cathode 


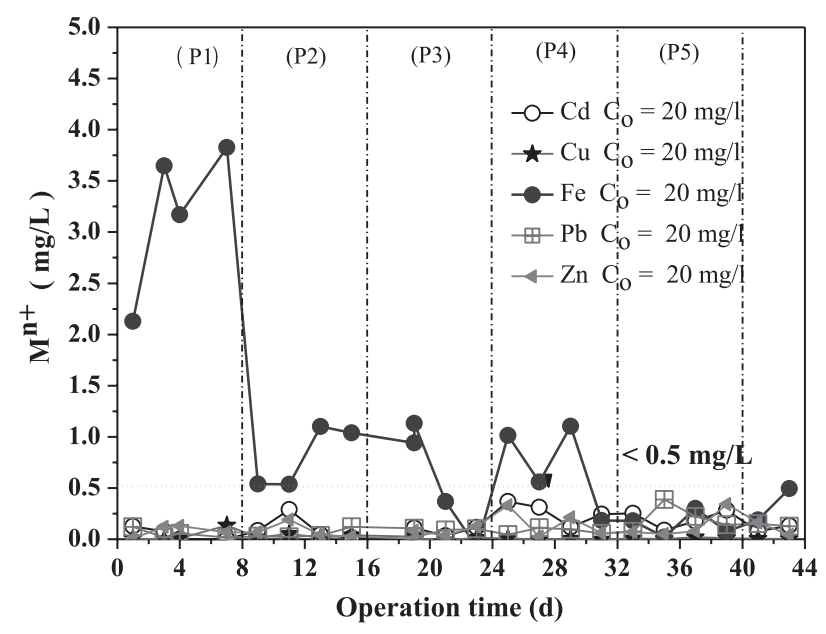

Fig. 3. Effluent of heavy metals concentrations for MFC-PRB reactor treating AMD.

surface accumulated in carbon felt. Previous studies have demonstrated that SRB converted sulphate into sulphide using the organic substrates as electron donors, then that generated heavy metals from the AMD as metal sulphides. SRB and other microbes play an essential role in the removal efficiency of heavy metals [36] (Eqs.1-2).

$$
\begin{gathered}
2 \mathrm{CH}_{2} \mathrm{O}+\mathrm{SO}_{4}{ }^{2-}+\mathrm{H}^{+} \stackrel{\mathrm{SRB}}{\rightarrow} \mathrm{H}_{2} \mathrm{~S}+2 \mathrm{HCO}_{3}^{-} \\
\mathrm{Me}^{2+}+\mathrm{H}_{2} \mathrm{~S} \rightarrow \mathrm{MeS} \downarrow-2 \mathrm{H}^{+}
\end{gathered}
$$

According to other studies on MFCs, excess sludge was not only a potential carbon source for use as electron donors for biological sulphate reduction, but also sulphate radicals can be served as electron acceptors in the MFC cathode, which was converted to hydrogen sulfide or sulfur ions in the biological cathode (Eqs. 3-4) [37, 38]. Moreover, the positive charge of heavy metal ions (for example $\mathrm{Cu}^{2+}$ ) in an MFC cathode solution is most likely to move to the cathode surface, here $\mathrm{Cu}^{2+}$ would get two electrons that can be reduced to elemental copper or $\mathrm{Cu}_{2} \mathrm{O}$ and copper (Eqs. 5-6).

$$
\begin{gathered}
\text { Anode : Sludge } \rightarrow \mathrm{CO}_{2}+\mathrm{H}_{2} \mathrm{O}+\mathrm{e}^{-} \\
\text {Cathode: } \mathrm{SO}_{4}{ }^{2-}+4 \mathrm{H}_{2} \mathrm{O}+8 \mathrm{e}^{-} \rightarrow \mathrm{S}^{2-}+8 \mathrm{OH}^{-} \\
2 \mathrm{Cu}^{2+}+2 \mathrm{H}_{2} \mathrm{O}+2 \mathrm{e}^{-} \rightarrow \mathrm{Cu}_{2} \mathrm{O}+\mathrm{H}_{2} \mathrm{O}+2 \mathrm{H}^{+} \\
\mathrm{Cu}^{2+}+2 \mathrm{e}^{-} \rightarrow \mathrm{Cu}
\end{gathered}
$$

\section{Conclusions}

This study simulated AMD being treated based on a novel coupled membrane-free microbial fuel cell with a permeable reactive barrier system. The following conclusions can be drawn from the experiments:

1. The MFC-PRB could continuously generate electricity from AMD, and the average sulphate removal rates of $51.2 \%, 39.8 \%$, and $33.1 \%$ were obtained in effluents of $1,000,2,000$, and $3,000 \mathrm{mg} / \mathrm{l}$, respectively.

2. High $\mathrm{Cu}^{2+}, \mathrm{Pb}^{2+}$, and $\mathrm{Zn}^{2+}$ removal efficiencies (99.5\%) were obtained during the operation, with most of the results in the range $0.01 \sim 0.05 \mathrm{mg} / 1$ - far below the level required by Chinese legislation $(0.5 \mathrm{mg} / \mathrm{l})$.

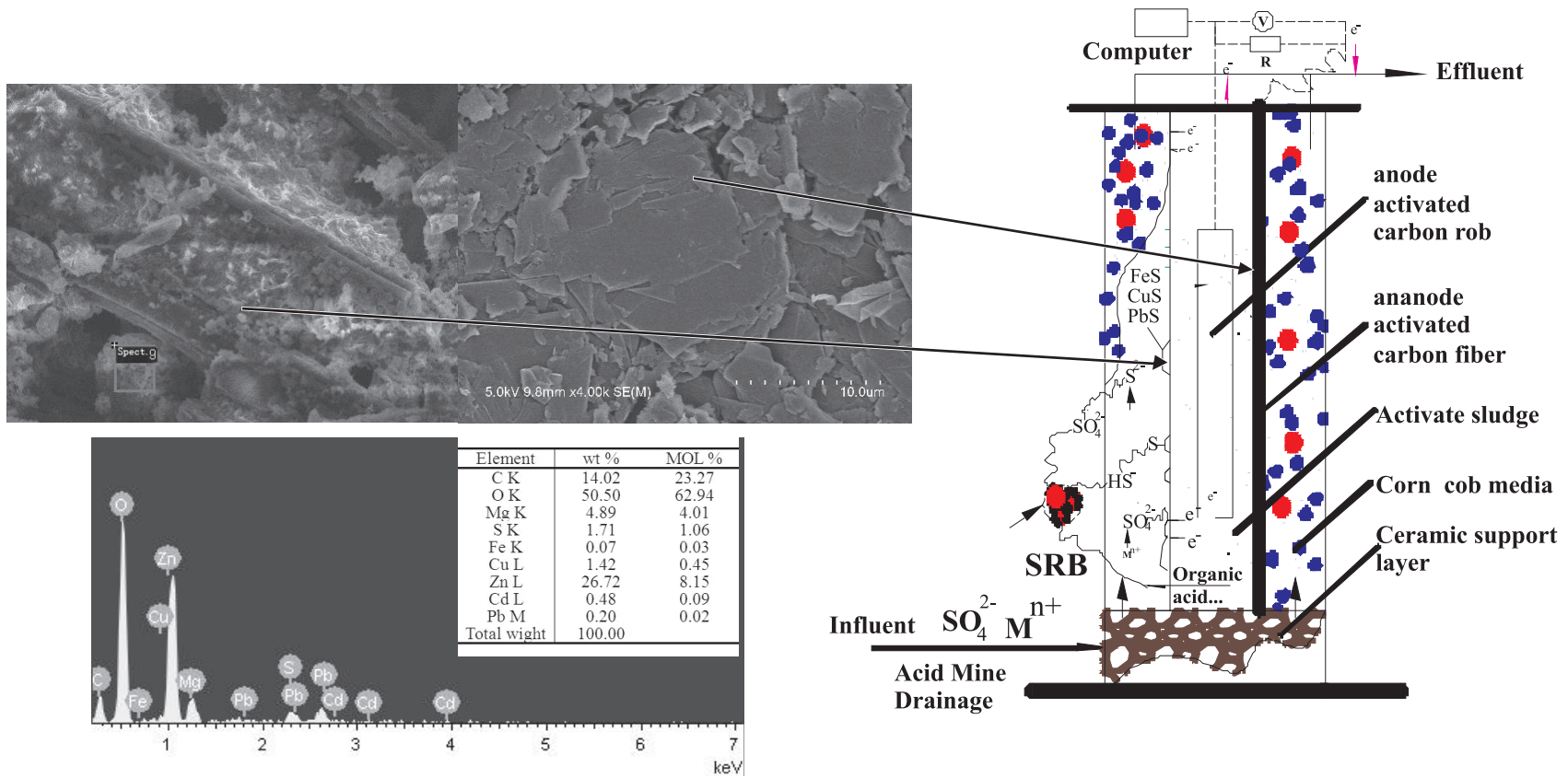

Fig. 4. MFC-PRB experimental setup and conversion of sulfur-compounds and heavy metals. 
These results suggest that the MFC-PRB holds the potential for simultaneous removal of heavy metals contained in AMD.

\section{Acknowledgements}

The authors are grateful for the financial support of the National Nature Science Foundation of China (Project No. 51274001), Natural Science Foundation of Anhui Province (1608085ME118) and The Key Program of Youth Elite Support Plan in Universities of Anhui Province (gxyqZD2016120).

\section{References}

1. DEMERS I., BOUDA M., MBONIMPA M., BENZAAZOUA M., BOIS D., GAGNON M. Valorization of acid mine drainage treatment sludge as remediation component to control acid generation from mine wastes, part 2: Field experimentation. Miner Eng. 76, 117, 2015.

2. MIGUEL M.G., BARRETO R.P., PEREIRA S.Y. Analysis of Aluminum, Manganese, and Iron Adsorption for the Design of a Liner for Retention of the Acid Mining Drainage. Water, Air, \& Soil Pollution. 226, 1, 2015.

3. UNDERWOOD B.E., KRUSE N.A., BOWMAN J.R. Longterm chemical and biological improvement in an acid mine drainage-impacted watershed. Environ Monit Assess. 186, 7539, 2014.

4. KIJJANAPANICH P., PAKDEERATTANAMINT K., LENS P., ANNACHHATRE A.P. Organic substrates as electron donors in permeable reactive barriers for removal of heavy metals from acid mine drainage. Environ Technol. 33, 2635, 2012.

5. LEFEBVRE O., NECULITA C.M., YUE X., NG H.Y. Bioelectrochemical treatment of acid mine drainage dominated with iron. J Hazard Mater. 241, 411, 2012.

6. RIEFLER R.G., KROHN J., STUART B., SOCOTCH C. Role of sulfur-reducing bacteria in a wetland system treating acid mine drainage. Sci Total Environ. 394, 222, 2018.

7. YIM G., JI S., CHEONG Y., NECULITA C.M., SONG H. The influences of the amount of organic substrate on the performance of pilot-scale passive bioreactors for acid mine drainage treatment. Environmental Earth Sciences. 73, 4717, 2012.

8. CHOUDHARY R.P., SHEORAN A.S. Performance of single substrate in sulphate reducing bioreactor for the treatment of acid mine drainage. Miner Eng. 39, 29, 2012.

9. BAI H., KANG Y., QUAN H., HAN Y., SUN J., FENG Y. Treatment of acid mine drainage by sulfate reducing bacteria with iron in bench scale runs. Bioresource Technol. 128, 818, 2013.

10. LIENDO M.A., HIDALGO G.E.N., SAMPAIO C.H., HECK N.C. Synthesis of ZVI particles for acid mine drainage reactive barriers: experimental and theoretical evaluation. Journal of Materials Research and Technology. 1, 75, 2012.

11. SU X., TIAN Y., SUN Z., LU Y., LI Z. Performance of a combined system of microbial fuel cell and membrane bioreactor: wastewater treatment, sludge reduction, energy recovery and membrane fouling. Biosensors and Bioelectronics. 49, 92, 2013.

12. DI NATALE F., DI NATALE M., GRECO R., LANCIA A., LAUDANTE C., MUSMARRA D. Groundwater protection from cadmium contamination by permeable reactive barriers. J Hazard Mater. 160, 428, 2008.
13. BENNER S.G., BLOWES D.W., GOULD W.D., HERBERT R.B., PTACEK C.J. Geochemistry of a permeable reactive barrier for metals and acid mine drainage. Environ Sci Technol. 33, 2793, 1999.

14. GIBERT O., DE PABLO J., LUIS CORTINA J., AYORA C. Evaluation of municipal compost/limestone/iron mixtures as filling material for permeable reactive barriers for in-situ acid mine drainage treatment. J Chem Technol Biot. 78, 489, 2008.

15. WAYBRANT K.R., BLOWES D.W., PTACEK C.J. Selection of reactive mixtures for use in permeable reactive walls for treatment of mine drainage. Environ Sci Technol. 32, $1972,1998$.

16. BLOWES D.W., PTACEK C.J., BENNER S.G., MCRAE C., PULS R.W. Treatment of dissolved metals and nutrients using permeable reactive barriers. J Contam Hydrol. 45, 123, 2000.

17. WAYBRANT K.R., PTACEK C.J., BLOWES D.W. Treatment of mine drainage using permeable reactive barriers: column experiments. Environ Sci Technol. 36, 1349, 2002.

18. GIBERT O., RÖTTING T., CORTINA J.L., DE PABLO J., AYORA C., CARRERA J., BOLZICOO J. In-situ remediation of acid mine drainage using a permeable reactive barrier in Aznalcollar (Sw Spain). J Hazard Mater. 191, 287, 2011.

19. ZIJLSTRA J., DESSI R., PERETTI R., ZUCCA A. Treatment of percolate from metal sulfide mine tailings with a permeable reactive barrier of transformed red mud. Water Environ Res. 82, 319, 2010.

20. GIBERT O., CORTINA J.L., DE PABLO J., AYORA C. Performance of a field-scale permeable reactive barrier based on organic substrate and zero-valent iron for in situ remediation of acid mine drainage. Environ Sci Pollut R. 20, 7854, 2013.

21. ZHANG H.Y., WANG B., DONG X.L., FAN Z.M., JU Y.Y. [Feasibility of sewage sludge used as filling material in permeable reactive barrier]. Huan jing ke xue=Huanjing kexue/ [bian ji, Zhongguo ke xue yuan huan jing ke xue wei yuan hui" Huan jing ke xue" bian ji wei yuan hui.]. 31, 1280, 2010.

22. FREGUIA S., TEH E.H., BOON N., LEUNG K.M., KELLER J., RABAEY K. Microbial fuel cells operating on mixed fatty acids. Bioresource Technol. 101, 1233, 2010.

23. CHENG S., JANG J., DEMPSEY B.A., LOGAN B.E. Efficient recovery of nano-sized iron oxide particles from synthetic acid-mine drainage (AMD) water using fuel cell technologies. Water Res. 45, 303, 2010.

24. ZHANG B., ZHANG J., LIU Y., HAO C., TIAN C., FENG C., LEI Z., HUANG W., ZHANG Z. Identification of removal principles and involved bacteria in microbial fuel cells for sulfide removal and electricity generation. Int J Hydrogen Energ. 38, 14348, 2013.

25. CHENG S., DEMPSEY B.A., LOGAN B.E. Electricity generation from synthetic acid-mine drainage (AMD) water using fuel cell technologies. Environ Sci Technol. 41, 8149, 2007.

26. ZHAI L., SONG W., TONG Z., SUN M. A fuel-cell-assisted iron redox process for simultaneous sulfur recovery and electricity production from synthetic sulfide wastewater. J Hazard Mater. 243, 350, 2013.

27. LUO H., FU S., LIU G., ZHANG R., BAI Y., LUO X. Autotrophic biocathode for high efficient sulfate reduction in microbial electrolysis cells. Bioresource Technol. 167, 462, 2014.

28. ZHANG B., ZHANG J., YANG Q., FENG C., ZHU Y., YE Z., NI J. Investigation and optimization of the novel UASBMFC integrated system for sulfate removal and bioelectricity generation using the response surface methodology (RSM). Bioresource Technol. 124, 1, 2012. 
29. ANGELOV A., BRATKOVA S., LOUKANOV A. Microbial fuel cell based on electroactive sulfate-reducing biofilm. Energ Convers Manage. 67, 283, 2013.

30. LEE D., LEE C., CHANG J. Treatment and electricity harvesting from sulfate/sulfide-containing wastewaters using microbial fuel cell with enriched sulfate-reducing mixed culture. J Hazard Mater. 243, 67, 2012.

31. RICE E.W., BRIDGEWATER L., Association APH. Standard methods for the examination of water and wastewater: American Public Health Association Washington, DC; 2012.

32. ZHENG B., LIU H. Electrochemical Sulfide Removal on Carbon Electrode in Sulfate Reducing Bacteria Microbiological Fuel Cell. ECS Transactions. 58, 1, 2014.

33. ZHANG B., ZHAO H., ZHOU S., SHI C., WANG C., NI J. A novel UASB-MFC-BAF integrated system for high strength molasses wastewater treatment and bioelectricity generation. Bioresource Technol. 100, 5687, 2009.

34. ZHAO F., RAHUNEN N., VARCOE J.R., CHANDRA A., AVIGNONE-ROSSA C., THUMSER A.E., SLADE R.C.T.
Activated carbon cloth as anode for sulfate removal in a microbial fuel cell. Environ Sci Technol. 42, 4971, 2008.

35. SANGCHAROEN A., NIYOM W., SUWANNASILP B.B. A microbial fuel cell treating organic wastewater containing high sulfate under continuous operation: Performance and microbial community. Process Biochem. 2015.

36. DE LIMA A., GONÇALVES M., GRANATO M., LEITE S Anaerobic sulphate-reducing microbial process using UASB reactor for heavy metals decontamination. Environ Technol. 22, 261, 2001.

37. CORD-RUWISCH R., WIDDEL F. Corroding iron as a hydrogen source for sulphate reduction in growing cultures of sulphate-reducing bacteria. Appl Microbiol Biot. 25, 169, 1986.

38. GANESH R., ROBINSON K.G., CHU L., KUCSMAS D., REED G.D. Reductive precipitation of uranium by Desulfovibrio desulfuricans: evaluation of cocontaminant effects and selective removal. Water Res. 33, 3447, 1999. 